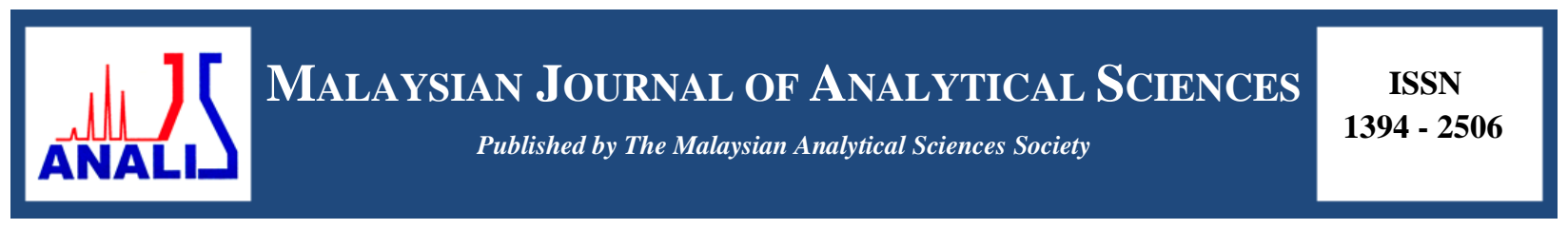

\title{
THERMAL, FLAMMABILITY, AND MORPHOLOGICAL PROPERTIES OF SEPIOLITE-FILLED ETHYLENE PROPYLENE DIENE MONOMER COMPOSITES
}

\author{
(Sifat Terma, Kemudahbakaran dan Morfologi bagi Komposit Etilena Propilena Monomer Diena \\ Terisi Sepiolit)
}

\author{
Nurul Aizan Mohd Zaini, Hanafi Ismail*, Arjulizan Rusli \\ School of Materials and Mineral Resources Engineering, Engineering Campus, \\ Universiti Sains Malaysia,14300 Nibong Tebal, Pulau Pinang, Malaysia \\ *Corresponding author: ihanafi@usm.my
}

Received: 20 July 2017; Accepted: 28 April 2018

\begin{abstract}
The effects of different sepiolite contents on the thermal stability, flammability, and morphological properties of sepiolite-filled ethylene-propylene-diene monomer composites were studied. These sepiolite-filled composites, containing 0-70 parts per hundred rubber (phr) of sepiolite fillers, were prepared through the conventional processing method of using a two-roll mill. The results demonstrated a significant increase in the thermal stability of the composites when sepiolite loading was increased compared to unfilled composites. The results also showed a decrease in the linear rate of burning of the composites with increasing sepiolite loading. The morphological study confirmed the presence of unburned sepiolite, which increased the flammability resistance of the composites.
\end{abstract}

Keywords: sepiolite, flammability, rubber, thermal stability, morphology

\begin{abstract}
Abstrak
Kesan kandungan sepiolit yang berbeza terhadap kestabilan terma, kemudahbakaran, dan ciri-ciri morfologi bagi komposit etilena-propilena-monomer diena terisi sepiolit telah dikaji. Komposit terisi sepiolit yang mengandungi 0 hingga 70 bahagian per seratus getah (bsg) telah disediakan melalui kaedah lazim menggunakan mesin pengisar bergulung dua. Keputusan menunjukkan peningkatan ketara pada kestabilan terma komposit apabila kandungan sepiolit ditambah berbanding dengan komposit tidak terisi. Hasil kajian turut menunjukkan penurunan kadar pembakaran selari komposit ini dengan penambahan kandungan sepiolit. Kajian morfologi mengesahkan kehadiran sepiolit yang tidak terbakar yang telah meningkatkan ketahanan kemudahbakaran komposit ini.
\end{abstract}

Kata kunci: sepiolit, kemudahbakaran, getah, kestabilan terma, morfologi

\section{Introduction}

The demand for clay minerals expands through various applications and their role has undoubtedly become more profound since the discovery of clay varieties at the end of the last century. Clay minerals are produced through the weathering process, in which the clay species experience changes through sedimentation and burial courses [1]. Clay minerals have long been incorporated in plastics or elastomer matrix as fillers. Clay-based materials have been most widely investigated among other potential nanocomposite alternatives, possibly due to the abundant sources of clay materials and because the study of their intercalation chemistry is already established [2]. Currently, the most 
intensive researches have been focused on layered silicates based on the smectite class of aluminum silicate clays, especially on montmorillonites (MMT) as the reinforcing phase [3]. However, these nanofillers are not the only type of nanoclays that can be incorporated into polymer matrices. Recently, several studies have focused on the use of sepiolite, a nanofiller with a needle-like morphology, to reinforce nanocomposites [4].

Sepiolite can be expressed as $\mathrm{Si}_{12} \mathrm{O}_{30} \mathrm{Mg}_{8}(\mathrm{OH})_{4}\left(\mathrm{OH}_{2}\right)_{4} \cdot\left(\mathrm{H}_{2} \mathrm{O}\right)_{8}[5,6]$, and it is also chemically known as the hydrated magnesium silicate [7]. This compound belongs to the 2:1 phyllosilicate structure; one octahedral sheet is sandwiched between two tetrahedral sheets. It is microfibrous, with $2-10 \mathrm{~mm}$ particles and exhibits nanosized tunnel structures $[8,9]$. The fibrous-like structure of sepiolite is believed to be more easily dispersed in the polymer matrix compared to platelet-like minerals, such as MMT [10]. Moreover, sepiolite can prevent flocculation when it is distributed within the network of a polymer and reduce filler agglomeration [5]. The presence of clay particles within a polymer matrix could enhance fire retardant properties. These particles can contribute to the formation of a char layer at the silicate surface, behaving as a barrier that reduces the oxygen transmission rate, retards the spread of flames, and help to keep the structural integrity of the burned sample [11]. As a potential filler, sepiolite offers promising advantages that could improve the mechanical, thermal, and flammability properties of the composites as well as reduce cost.

Polymer matrices, such as natural rubber [12,13], nitrile rubber [14], styrene butadiene rubber [15, 16], silicone rubber [17], acrylonitrile butadiene styrene [18], polyether imide [19], and polyamide 6 [20] have been filled with sepiolite to improve their properties. However, little attention has been paid to the properties of sepiolite in ethylene-propylene-diene monomer (EPDM). Wang et al. [21] conducted several preliminary investigations based on the surface free energy of EPDM/Sepiolite nanocomposites. However, they had only reported a limited number of properties of the EPDM/Sepiolite composites. Therefore, further studies are necessary to generate positive results from the various properties of the sepiolite-filled EPDM composites.

Based on a literature survey, none of the previous reports have dealt with the effects of sepiolite on the thermal stability, flammability, and morphology of the char residue of EPDM/Sepiolite composites. Thus, this study has focused on investigating the potential effects of using sepiolite as fillers on the thermal stability, flammability, and morphological properties of EPDM/Sepiolite composites at various loadings.

\section{Materials}

\section{Materials and Methods}

The EPDM used in this study was Vistalon $2504 \mathrm{~N}$ that contained $54 \%$ ethylene, with $3.6 \%$ of ethylidene norbornene (ENB) and Mooney viscosity [ML $(1+4)$ at $\left.125^{\circ} \mathrm{C}\right]$ of 26.8 (Mooney Unit), which was purchased from ExxonMobil. The density of the EPDM was $0.818 \mathrm{~g} / \mathrm{cm}^{3}$ as measured using an analytical balance (Precisa, model XB 220A). The sepiolite clay was purchased from Hebei DFL Minmet Refractories Corp., China. Meanwhile, other compounding ingredients were purchased from Bayer (M) Ltd., namely, zinc oxide, stearic acid, tetramethyl thiuram disulphide (TMTD), mercaptobenzothiazole (MBT), and sulphur.

\section{Sample preparation}

The sepiolite was dried in an oven for 24 hours at $80{ }^{\circ} \mathrm{C}$ before mixing to remove any existing moisture. Table 1 lists the compounding formulations for EPDM/Sepiolite composites, in which each compound was prepared using a laboratory scale $\left(160 \times 320 \mathrm{~mm}^{2}\right)$ and a two-roll mill (model XK-160). All composites were mixed for 21 minutes according to the ASTM D3568. The optimum cure time $\left(t_{90}\right)$ and scorch time $\left(t_{\mathrm{s} 2}\right)$ were obtained by utilising the Monsanto Moving Die Rheometer (model MDR2000) at $160{ }^{\circ} \mathrm{C}$. Based on their respective $t_{90}$ values, the compounds were compression moulded into $3 \mathrm{~mm}$ rectangular sheets, with a dimension of $125 \mathrm{~mm} \times 13 \mathrm{~mm} \times 3$ $\mathrm{mm}$ using the KAO-Tieh GO Tech Compression Moulding Machine, at $160{ }^{\circ} \mathrm{C}$ with a force of $10 \mathrm{MPa}$. 
Table 1. Compounding formulations for EPDM/Sepiolite Composites (phr)

\begin{tabular}{lc}
\hline Materials & Content (phr) \\
\hline EPDM & 100 \\
Zinc Oxide & 5 \\
Stearic Acid & 1.5 \\
TMTD $^{\mathrm{a}}$ & 1.5 \\
MBT $^{\mathrm{b}}$ & 0.8 \\
Sulphur & 1.5 \\
Sepiolite & $0,10,20,30,70$ \\
\hline
\end{tabular}

${ }^{a}$ Tetramethyl thiuram disulphide,

${ }^{\mathrm{b}}$ Mercaptobenzothiazole

\section{Thermal analysis}

Thermogravimetric analysis (TGA) was performed on $10 \mathrm{mg}$ samples that were heated from 30 to $600{ }^{\circ} \mathrm{C}$ at a ramp rate of $20^{\circ} \mathrm{C} / \mathrm{min}$, under nitrogen flow $(50 \mathrm{~mL} / \mathrm{min})$ using a Perkin Elmer Pyris 6 thermogravimetric analyser. The analysis involved measuring weight loss as a function of temperature where the TGA curve was recorded.

\section{Flammability test}

The samples' flammability was tested using the horizontal burning test in accordance with ASTM D635. Initially, samples with a dimension of $125 \mathrm{~mm} \times 13 \mathrm{~mm} \times 3 \mathrm{~mm}$ were prepared. The flame was ignited on one end of the sample using natural gas. The burnt length and the time for the flame front to reach the $25 \mathrm{~mm}$ reference mark, and travel to the $100 \mathrm{~mm}$ reference mark were recorded. Equation (1) was used to calculate the linear rate of the burning samples.

$$
V=60 L / t
$$

where $\mathrm{V}$ is the linear burning rate, $\mathrm{L}$ is the burnt length, and $\mathrm{t}$ is the time in minutes [22].

\section{Morphological study}

The morphology of the charred surfaces of the EPDM/Sepiolite composites was examined under the Zeiss Supra 35VP field emission scanning electron microscope (FESEM) at 1,000x magnification. The test specimens were first coated with a thin layer of gold-palladium. The coating was necessary to eliminate any electrostatic charges during the examination.

\section{Thermal stability analysis}

\section{Results and Discussion}

Figure 1 and Table 2 present the thermal degradation properties of EPDM/Sepiolite composites in comparison with unfilled EPDM compound. In general, weight loss is used to determine the thermal stability of the polymer composites. The heating process will prompt the production of volatile products, hence reducing the weight of the compound [23]. 


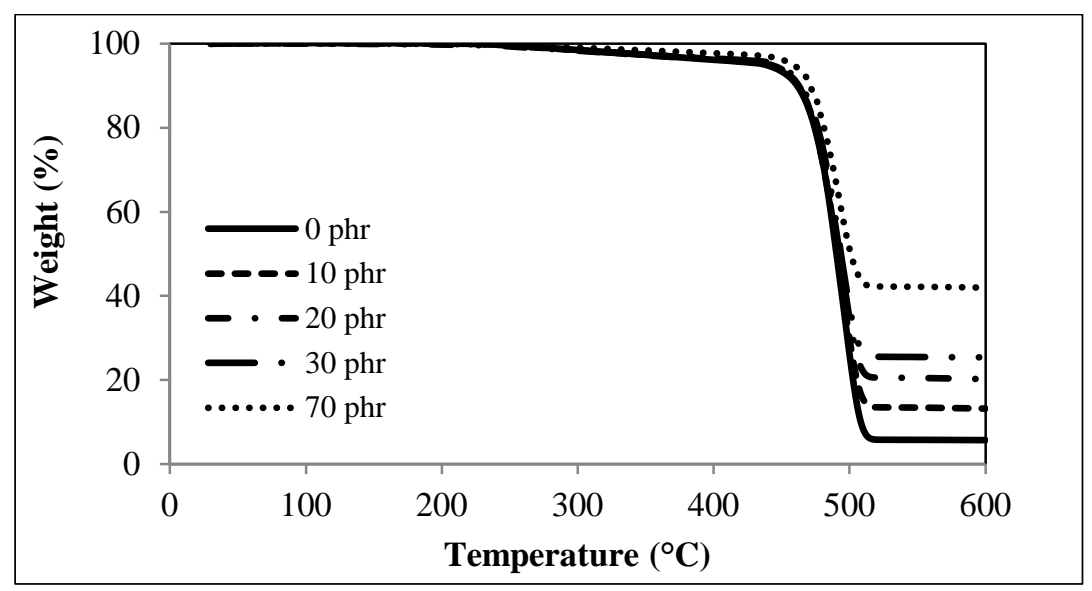

Figure 1. TGA curves for unfilled EPDM and sepiolite-filled EPDM composites

Table 2. Thermal properties of unfilled EPDM and sepiolite-filled EPDM composites

\begin{tabular}{lcccc}
\hline $\begin{array}{l}\text { Sepiolite Content } \\
(\mathbf{p h r})\end{array}$ & $\begin{array}{c}\text { Temp at 5\% wt. } \\
\text { Loss }\left({ }^{\circ} \mathbf{C}\right)\end{array}$ & $\begin{array}{c}\text { Temp at 50\% wt. } \\
\text { Loss }\left({ }^{\circ} \mathbf{C}\right)\end{array}$ & $\begin{array}{c}\text { Max wt. } \\
\text { Loss }(\%)\end{array}$ & $\begin{array}{c}\text { Char Residue at } \\
\mathbf{6 0 0}^{\circ} \mathbf{C}(\mathbf{\%})\end{array}$ \\
\hline 0 & 432 & 489 & 56.4 & 5.7 \\
10 & 438 & 491 & 52.3 & 13.2 \\
20 & 440 & 492 & 44.1 & 20.2 \\
30 & 446 & 494 & 42.3 & 25.4 \\
70 & 458 & 500 & 34.5 & 41.9 \\
\hline
\end{tabular}

Overall, all sepiolite-filled EPDM composites exhibited improved thermal stability. The data showed that the incorporation of sepiolite into the EPDM matrix had increased the overall thermal stability of the composites because sepiolite acted as a thermal insulator [24]. For instance, the temperature at 5\% of weight loss of unfilled EPDM compound was at $432{ }^{\circ} \mathrm{C}$, while $70 \mathrm{phr}$ of sepiolite in the EPDM had increased the temperature up to 458 ${ }^{\circ} \mathrm{C}$. The char residue at $600{ }^{\circ} \mathrm{C}$ was increased from 5 to $41 \%$, with sepiolite clay loadings that ranged between 0 to $70 \mathrm{phr}$. This result indicated that sepiolite was the mass transport barrier [17]. Reduction in the thermal energy transfer had halted the thermal degradation process, while the decomposition process was hindered by the fibrous structure of the sepiolite. These deterrents had resulted in the reduced rate of volatility loss, and higher amount of residues. Additionally, the well-dispersed sepiolite may have restricted the mobility of the polymer chains, which led to the delayed heating.

\section{Flammability analysis}

Figure 2 displays the effect of different sepiolite loadings on the flammability of EPDM/Sepiolite composites, as determined by the linear rate of burning. The linear rate of burning was reduced when sepiolite concentration was increased. The EPDM composite with $70 \mathrm{phr}$ sepiolite exhibited the longest burnout time compared to the unfilled composites and subsequently, exhibited the lowest linear rate of burning. The linear rate of burning agreed with the thermal properties of the composites, as previously discussed. The fibrous structure of the sepiolite and the formation of carbonaceous char layers during the burning process had contributed to the fire resistance nature of these composites [25]. During the burning process, sepiolite had formed a protective layer of char on the matrix surface, by acting as an insulating barrier against oxygen, and preventing heat from reaching the underlying matrix. Therefore, the amount of decomposed volatiles that escaped from the interior polymer matrix was reduced, which resulted in a longer time to burn, and subsequently, reduced the linear rate of burning. This process was further inhibited by the formation of char at higher filler loadings, which shielded 
the underlying EPDM matrix from heat.

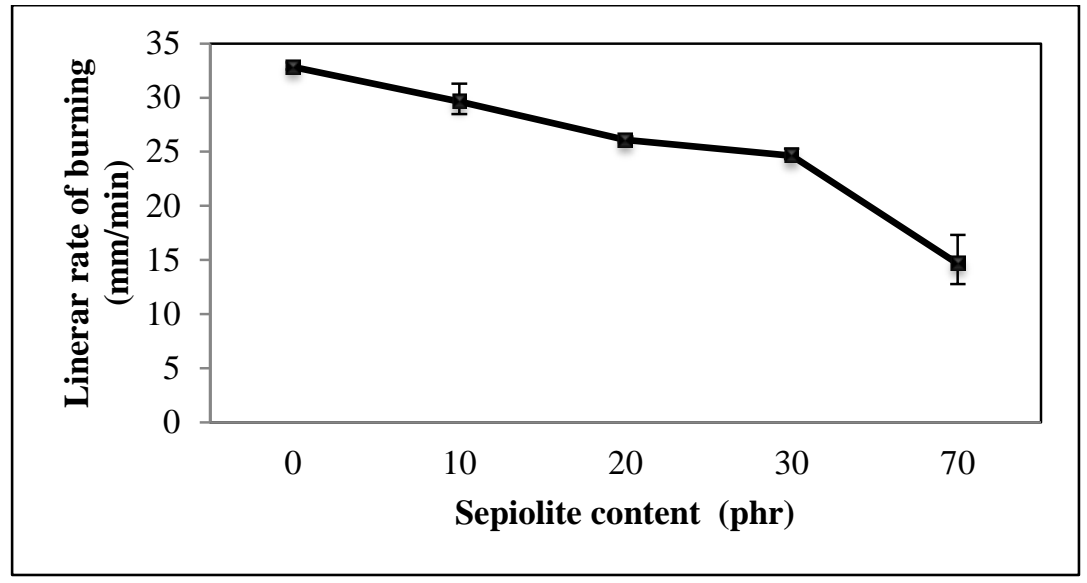

Figure 2. The effect of different sepiolite loadings on the flammability of EPDM/Sepiolite composites

\section{Morphologies of charred surfaces}

Figures 3(a) and (b) show the charred surfaces of EPDM/Sepiolite composites at 30 and $70 \mathrm{phr}$ of sepiolite loadings, respectively. The $30 \mathrm{phr}$ sepiolite, as observed in Figure 3(a), had delayed the burning time of the composite due to the presence of unburned sepiolite. The unburned sepiolite had impeded the transport of flammable vapour, thus reducing the flammability rate of the EPDM/Sepiolite composite. This observation confirmed the reduction of the linear rate of burning and the increment of char residues of the EPDM/Sepiolite composites, as shown by the TGA results when the sepiolite loadings were increased.

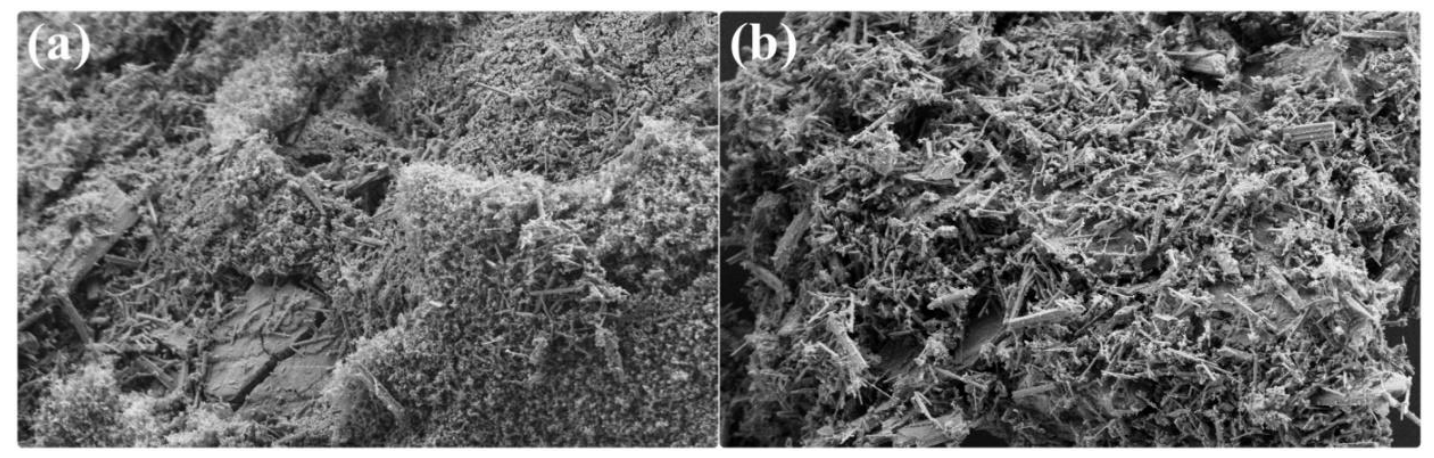

Figure 3. Char residues collected following the flammability test of EPDM/Sepiolite composites, with sepiolite loadings of: (a) $30 \mathrm{phr}$; and (b) $70 \mathrm{phr}$ at 1,000× magnification

\section{Conclusion}

The thermal stability of the EPDM/Sepiolite composites was remarkably improved with increased clay loadings compared to the thermal stability of the unfilled compound. Sepiolite had acted as a thermal insulator by reducing the transfer of thermal energy through the composites. The presence of unburned sepiolite had reduced the linear rate of burning of the EPDM/Sepiolite composites. FESEM micrographs confirmed that the unburned sepiolite particles had created a protective barrier, which reduced the linear rate of burning.

\section{Acknowledgement}

The authors wish to thank the management and staff members at the Department of Materials and Mineral Resources Engineering, Universiti Sains Malaysia (USM) for providing the research facilities that made this 
research project possible. One of the authors is grateful to the Ministry of Higher Education Malaysia (KPT(BS)821115065540) and Universiti Teknologi Mara (UiTM) (600-BPD(PKH.1/2/9946) for the financial support under their scholarships.

\section{References}

1. Velde, B. (1992). Introduction to clay minerals- chemistry, origin, uses and environmental significance. First edition. Chapman and Hall, London.

2. Pavlidou, S. and Papaspyrides, C.D., (2008). A review on polymer-layered silicate nanocomposites. Progress in Polymer Science, 33(11): 1119-1198.

3. Nguyen, Q. T. and Baird, D. G. (2006). Preparation of polymer-clay nanocomposites and their properties. Advances in Polymer Technology, 25(4): 270-285.

4. Zaini, N. A. M., Ismail, H. and Rusli, A. (2017). Short review on sepiolite filled polymer nanocomposites. Polymer- Plastics Technology and Engineering, 56(15): 1665-1679.

5. Olivato, J. B., Marini, J. and Yamashita, F. (2017). Sepiolite as a promising nanoclay for nano-biocomposites based on starch and biodegradable polyester. Materials Science and Engineering C, 70: 296-302.

6. Zotti, A., Borriello, A. and Ricciardi, M., (2015). Effects of sepiolite clay on degradation and fire behaviour of a bisphenol A-based epoxy. Composites Part B Engineering, 73: 139-148.

7. Tartaglione, G., Tabuani, D., Camino, G. and Moisio, M. (2008). PP and PBT composites filled with sepiolite: Morphology and thermal behaviour. Composites Science and Technology, 68(2) :451-460.

8. Kotal, M and Bhowmick, A. K. (2015). Polymer nanocomposites from modified clays: Recent advances and challenges. Progress in Polymer Science, 51: 127-187.

9. Chen, H., Lu, H. and Zhou, Y., (2012). Study on thermal properties of polyurethane nanocomposites based on organo-sepiolite. Polymer Degradation and Stability, 97(3): 242-247.

10. Liu, M., Pu, M. and Ma, H. (2012). Preparation, structure and thermal properties of polylactide/sepiolite nanocomposites with and without organic modifiers. Composites Science and Technology, 72(13): 1508-1514.

11. Darder, M., Matos, C. R. S. and Aranda, P., (2016). Bionanocomposite foams based on the assembly of starch and alginate with sepiolite fibrous clay. Carbohydrate Polymers, 157: 1933-1939.

12. Lowe, D. J., Chapman, A. V., Cook, S. and Busfield, J. J. C. (2011). Natural rubber nanocomposites by in situ modification of clay. Macromolecular Materials and Engineering, 296(8): 693-702.

13. Bhattacharya, M. and Bhowmick, A.K. (2010). Synergy in carbon black-filled natural rubber nanocomposites. Part I: Mechanical, dynamic mechanical properties, and morphology. Journal of Materials Science, 45(22): 6126-6138.

14. Takei, T., Oda, R. and Miura, A. (2013). Effect of dispersion of sepiolite in sepiolite-NBR composite on the tensile strength. Composites Part B Engineering, 44(1): 260-265.

15. Bhattacharya, M., Maiti, M. and Bhowmick, A. K. (2009). Tailoring properties of styrene butadiene rubber nanocomposite by various nanofillers and their dispersion. Polymer Engineering and Science, 49(1): 81-98.

16. Bokobza, L., Leroy, E. and Lalanne, V. (2009). Effect of filling mixtures of sepiolite and a surface modified fumed silica on the mechanical and swelling behavior of a styrene-butadiene rubber. European Polymer Journal, 45(4): 996-1001.

17. Roy, N. and Bhowmick, A. K. (2010). Novel in situ polydimethylsiloxane-sepiolite nanocomposites: Structureproperty relationship. Polymer, 51(22):5172-5185.

18. Basurto, F. C., García-López, D. and Villarreal-Bastardo, N. (2012). Nanocomposites of ABS and sepiolite: Study of different clay modification processes. Composites Part B Engineering, 43(5): 2222-2229.

19. Tabatabaei-Yazdi Z. and Mehdipour-Ataei S. (2015). Poly(ether-imide) and related sepiolite nanocomposites: investigation of physical, thermal, and mechanical properties. Polymer for Advanced Technologies, 26(4): 308314.

20. Bilotti, E., Duquesne, E. and Deng, H. (2014). In situ polymerised polyamide 6/sepiolite nanocomposites: Effect of different interphases. European Polymer Journal, 56(1): 131-139.

21. Wang, F, Tang, Q.G. and Chen, C. (2013). Effect of Sepiolite Nanofibers on Properties of EPDM Nanocomposites. Applied Mechanics and Materials, 320: 595-598.

22. America Society for Testing and Materials (2010). Standard Test Method for Rate of Burning and/or Extent and Time of Burning of Plastics in Horizontal Position. ASTM D635-10. 
23. Bidsorkhi, H. C., Adelnia, H. and Naderi, N. (2015). Ethylene vinyl acetate copolymer nanocomposites based on (un)modified sepiolite: Flame retardancy, thermal, and mechanical properties. Polymer Composites, 38(7): $1302-1310$.

24. Chen, H., Zheng, M., Sun, H. and Jia, Q. (2007). Characterization and properties of sepiolite/polyurethane nanocomposites. Materials Science Engineering:A, 445-446 (25): 725-730.

25. Munusamy, Y., Ismail, H., Mariatti, M. and Ratnam, C. T. (2009). Effects of different preparation methods on the properties of poly[ethylene-co-(vinyl acetate)]/(Standard Malaysian natural rubber)/organoclay nanocomposites. Journal of Vinyl Additive and Technology, 15: 244-251. 